\title{
Effects of Occupational Hazards on Mental and Reproductive Health of Women in Nepal
}

\author{
Pralhad Adhikari* \\ Department of Philosophy and Psychology, Tri Chandra Campus, Nepal
}

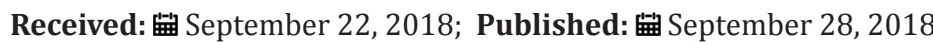

*Corresponding author: Pralhad Adhikari, Department of Philosophy and Psychology, Tri Chandra Campus, Nepal

\begin{abstract}
Women constitute 51.5 percent of Nepal's population. Their socioeconomic condition is very backward. Because of forced or early marriage, women are compelled to work as breadwinner of family or worker of household. Some women have obligation to work during pregnancy or immediately after delivery. Since many male cohorts have gone abroad, society resorts to women for labor. Occupational hazards of women are different based on geography, rural-urban environment, ethnicity (or caste) and even religion. Commonest of them are lack of safety devices, sexual harassment, domestic/workplace violence, injuries and occupational diseases. Their effects on psychology are lowered dignity (including self-esteem), trauma, melancholy, depression, early aging and other neurotic disorders. Their effects on reproductive health are sexual deprivation, uterine prolapse, molestation at workplace, marital rape, sexually transmitted diseases (STDs), extramarital affairs and polygamy.
\end{abstract}

Keywords: pregnancy; occupational health psychology; sexual deprivation; Kathmandu

\section{Introduction}

Women span 51 percent of population in the world. This percent is 51.5 for Nepal Central Bureau of Statistics [1]. Female working age population is $61.6 \%$ whereas such male population is $55.3 \%$ UNFPA Nepal [2]. Many men have emigrated abroad to earn their bread. Female are little different from male in biology and physique. Their socioeconomic standard is inferior than male's historically. For example, it is gender norm to drop female child of 12 or 13 out of school Hunt \& Samman [3] in many districts. Many families still depend on agriculture. Millions of men have gone for foreign employment to earn money. So, women alone take care of properties and family members. They work in fields, rear cattle and make food. They take care of children and old in-laws. Farmer women work without safety equipment. They contract wounds, allergies, abrasions, fall, and sometimes gender-based violence. For the occupations that are more risk-prone, occupational hazards are more. For example, traffic policewomen, farmers and construction laborers are vulnerable to stress and injuries O'Driscoll \& Brough [4]. Even in white collared jobs, women face various hazards like harassment, socio-cultural biases, and slighting like by being given inferior tasks Christie \& Giri [5]. Farmer women spray pesticides without gloves and masks. Construction workers carry materials without helmet or go to heights without safety belts. Female civil servants may be molested by bosses. Rising women doctors may be slandered. Central Bureau of Statistics said that 74.8 percent female represent unpaid family labor force care [6]. It means women have low economic say. Hence, they have to suffer even though they work more. Gender stereotype about occupations restricts women from going to senior management or high-paying jobs. Most women start with a minimum level of education Acharya [7]. It is a major factor because of which they cannot manage hazards caused owing to social or legal issues. There is no distinction between work and family for women in informal sectors. Work-family conflict is more detrimental for women O’Driscoll \& Brough [4].

\section{Effect of Occupational Hazards on Mental Health}

Working women are vulnerable to stress and depression. They get fatigued or even exhausted. Work overload is a major occupational hazard of Nepalese women. This is a major factor of early aging of rural women. They do works in field, rear cattle, take care of family members and prepare food. Inadequate sleep is a possibility and sleep deprivation might be the result. Accidents and injuries are very common. Farmer women may break their leg, break hands, get cuts, get abrasion, fall off cliff (as Nepal constitutes of very mountainous topography), and get stepped or dragged by cattle. Women carry grass on a doko (basket) using namlo (plastic strap) hung to head. This gives headache and rarely broken neck. Allergies among farmer women are not uncommon. Kathmandu is a pollution icon. Women commuting in scooters are vulnerable 
to asthma, bronchitis and even cancer. The fear of contracting respiratory and mental diseases gives them irritation as a habitual response Adhikari [8]. They get flooded by dust and smoke. Women trafficking is a great problem in Nepal. Many Nepalese girls are sold by force, fraud, and coercion in the capital Kathmandu, India and Gulf countries for sex slavery. Raped up to 35 times a day, such women experience trauma Diyali [9]. After civil war of a decade, Nepali women also started to go abroad legally or illegally. Since they are uneducated and lack skills, they are employed as housemaids. Their sexual and labor exploitation is highly possible.

Unemployment is a major stressor for educated women. Still, it is more stressful for girls and women from poor families. Many educated women go to developed nation like Australia, the US, and Japan for further education. Due to maladaptation, relationship issues, loneliness and economic difficulty, they are committing suicide at a frightening rate. Employed women in districts like Bara and Banke are more insecure because of not being hired permanently, pressure from family to refrain from work, fear of assault at night and inability to report abuses to authority Coyle, Shrestha, \& Thapa [10]. In male-dominated professions like engineering, women face societal disbelief and collegial jealousy Shrestha [11]. The psychological effects of such occupational hazards are trauma, sometimes post-traumatic stress disorder (PTSD), anxiety disorders, depression, loss of dignity, suicide attempts, lowered self-esteem, loss of trust from men, early aging, loss of freedom (autonomy), absenteeism, injuries, disability, musculoskeletal disorders and other occupational diseases.

\section{Effect of Occupational Hazards on Reproductive Health}

Availability of minimum facilities dictated by laws has not been realized yet. For example, Labor Act 1992 specifies that an employer should have a child care center if the organization has more than 50 women working. Child care center is almost non-existent Gautam \& Prasain [12]. The effect is women have to leave the job or stay on leave for very long. There are not good provisions of toilets or rest rooms. So, women drink very little liquid (i.e. water) when they have to go to offices or factories. Most of the toilets are found unsanitary and female-hostile when they are to be used despite unwillingness e.g. during menstruation. Because farmer women work alone very hard and expend labor to tend farm and cattle and husbands go to cities or abroad to earn money, they suffer from early aging. While the women seem too old, their husbands get married again. As depicted in blockbuster picture Chhakkapanja of 2016, tragedy of young couple can cause sexual deprivation and hence extramarital affairs and further spoilt families. Consequence is gender-based violence such as murder of wife or lover at the extreme. When there is extreme stress or burnout, women may suffer from biopathology like urogenital infection Sznajder et al. [13]. In some communities, women are isolated to lowly sheds during menstruation- a practice known as chhaupadi. They are prone to risk of snakebite or rape then care [6]. In some matriarchal communities like Tharu, women may have better social position. However, most rural women are obligated to carry heavy loads during pregnancy. They also are constrained to resume informal works immediately after delivery of baby. Uterine prolapse is an alarming problem in Nepalese women. Very few women, those of city and higher socioeconomic class, go through safe pregnancy and proper post-natal resilience. Nursing women get little assistance. They might contract carpal tunnel syndrome more. Because women are unwilling to have sex because of occupational diseases, they may be prone to marital rape. Husbands from many villages who go to India might visit brothel and contract sexually transmitted disease like HIV AIDS. They unknowingly give this gift to their wives who take care of their properties and children back home. Husbands die soon, and their sexual life becomes a disaster. Reproductive effects of occupational hazards are manifold. Menstruation becomes a problem, rather than a routine biological process. Women are raped, and raped women are outcast from family. Separated spouses suffer from sexual deprivation and resort to deviant fulfillment methods like extramarital affairs (or visiting brothels). Women may contract STDs from husbands who visited brothels. Women suffer from uterine prolapse because of carrying heavy loads during pregnancy, returning to labor-intensive works without resilience after delivery or birthing frequently. Marital rape is a possibility. Childless women are stigmatized more in sorority World Health Organization [14]. Many women die while giving birth to child because of economic difficulty and low decision power. Women workers get exactly half the wages of men workers in informal workplaces.

\section{Conclusion}

Women seem like labor robots and sexual objects in Nepalese society. Working women in Nepal live a life of low dignity. Their occupational hazards are too many. Women should get to live a life of high self-esteem and dignity because they work to support family, rear children, take care of old family members and prepare food. Occupational hazards have messed women psychologically and reproductively but there are ways to solve these problems with the help of occupational health psychology and gynecology.

\section{References}

1. Central Bureau of Statistics (2016) 2015 Statistical Year Book: Nepal. Government of Nepal, Kathmandu, Nepal, India.

2. UNFPA Nepal (2017) Population Situation Analysis of Nepal (With Respect to Sustainable Development).

3. Hunt A, Samman E (2016) Women's economic empowerment Navigating enablers and constraints. Overseas Development Institute, London, UK.

4. O'Driscoll MP, Brough P (2010) Work Organization and Health. In S Leka \& J Houdmont (Eds.), Occupational Health Psychology. Oxford: WileyBlackwell, pp. 57-87.

5. Christie ME, Giri K (2011) Challenges and experiences of women in the forestry sector in Nepal. International Journal of Sociology and Anthropology 3(5): 139-146.

6. Care (2015) Gender relations in Nepal overview: care, Switzerland.

7. Acharya S (2015) Gender, Jobs and Education Prospects and Realities in Nepal. Kathmandu, UNESCO. 
8. Adhikari P (2018) Talking about mental health from the most polluted city. MOJ Public Health 7(3): 86-87.

9. Diyali S (2017) Trafficking of Women in Nepal and their Vulnerabilities. International Development, Community and Environment (IDCE), 101.

10. Coyle D, Shrestha R, Thapa CJ (2014) Women's insecurities and the workplace in Nepal: A study from Banke and Bara districts. Kathmandu: Forum for Women, Law and Development, Safe World, UK.

11. Shrestha GK (2016) Understanding the Challenges of Women in Nontraditional Occupations. Journal of Training and Development, Volume 2.
12. Gautam RP, Prasain JN (2011) Current Situation of Occupational Safety and Health in Nepal. A study report. Kathmandu, Nepal.

13. Sznajder KK, Harlow SD, Burgard SA, Wang Yr, Han C, et al. (2014) Urogenital infection symptoms and occupational stress among women working in export production factories in Tianjin, China. Asian Pacific Journal of Reproduction 3(2): 142-149.

14. World Health Organization (2009) Women and health: today's evidence tomorrow's agenda. Geneva: World Health Organization.

\section{(C) \\ This work is licensed under Creative Commons Attribution 4.0 License}

To Submit Your Article Click Here:

Submit Article
DOI: $10.32474 /$ IGWHC.2018.02.000147

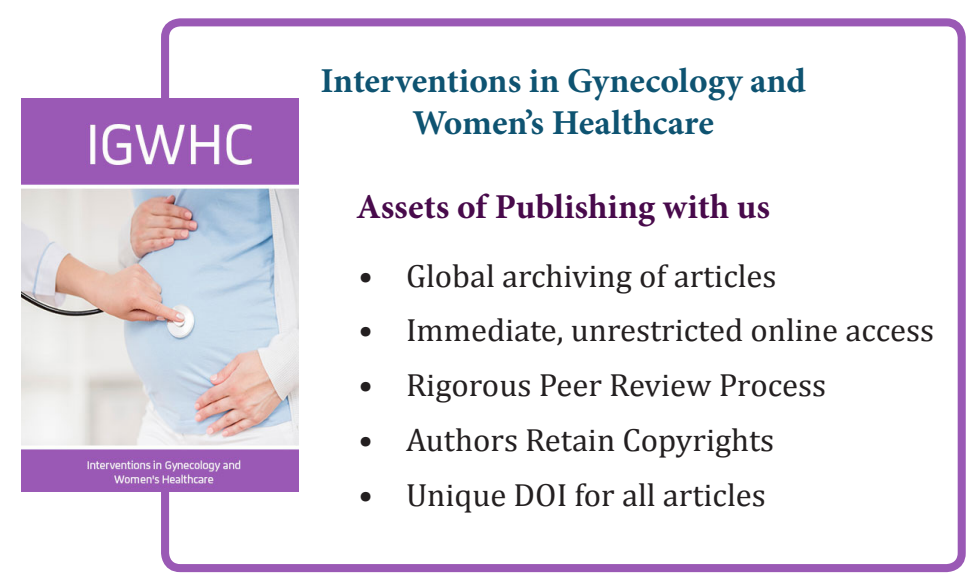

